\title{
Pengolahan Ubi Jalar Menjadi Aneka Olahan Makanan : Review
}

\section{Rinjani Alam Pratiwi ${ }^{1 *}$}

${ }^{1}$ Balai Pengkajian Teknologi Pertanian Papua Barat

\begin{tabular}{l}
\hline \multicolumn{1}{c}{ ARTIKEL INFO } \\
\hline Sejarah artikel \\
Diterima 04/11/2020 \\
Diterima dalam bentuk revisi 12/12/2020 \\
Diterima dan disetujui $15 / 12 / 2020$ \\
Tersedia online 23/12/2020 \\
\hline Kata kunci \\
Olahan makanan \\
Pengolahan \\
Ubi jalar \\
\hline
\end{tabular}

\begin{abstract}
ABSTRAK
Ubi jalar merupakan salah satu komoditas pangan lokal yang mudah untuk dibudidayakan, khususnya di Papua Barat ada beberapa varietas lokal ubi jalar yang dihasilkan. Selama ini ubi jalar hanya dikonsumsi oleh masyarakat dalam bentuk utuh seperti direbus, digoreng, dibakar dan dikukus. Aneka umbi merupakan komoditas pertanian yang mempunyai kadar air tinggi, yaitu antara 60-70 persen sehingga umur simpan jauh lebih pendek dibandingkan dengan serealia dan kacangkacangan. Kandungan zat gizi ubi jalar juga cukup lengkap bahkan beberapa zat diantaranya sangat penting bagi tubuh karena berfungsi fisiologis yaitu antosianin dan karatenoid sebagai anti oksidan serta serat rapinasa yang berfungsi prebiotik. Antosianin juga memiliki kemampuan sebagai antimutagenik dan antikarsinogenik terhadap mutagen dan karsinogen yang terdapat pada bahan pangan dan olahannya, serta dapat mencegah gangguan pada fungsi hati, antihipertensi dan menurunkan kadar gula darah. Pengolahan ubi jalar menjadi tepung merupakan salah satu cara untuk menyimpan dan mengawetkan ubi jalar. Pemanfaatan ubi jalar sebagai sumber pangan dapat juga dijadikan sebagai bahan baku industri. Pengolahan ubi jalar juga semakin bervariasi seiring makin meningkatnya produksi ubi jalar ungu. Pengolahan menjadi tepung adalah salah satu bentuk produk olahan yang dapat meningkatkan kemandirian bangsa dengan mengurangi penggunaan tepung terigu. Ubi jalar dapat diolah menjadi aneka olahan moderen. Beberapa olahan makanan yang berasal dari ubi jalar adalah roti tawar, bolu kukus, mie ubi jalar, stik ubi jalar, selai ubi jalar, es krim dan saos ubi jalar.
\end{abstract}

(C) 2020 Politeknik Pembangunan Pertanian Manokwari 


\section{ABSTRACT}

Sweet potato is one of the local food commodities that is easy to cultivate, especially in West Papua there are several local varieties of sweet potato produced. So far, sweet potatoes are only consumed by people in their whole form, such as boiling, frying, roasting and steaming. Various tubers are agricultural commodities that have a high water content, which is between 60-70 percent so that the shelf life is much shorter than cereals and nuts. The nutritional content of sweet potatoes is also quite complete, even some of which are very important for the body because of their physiological functions, namely anthocyanins and caratenoids as antioxidants and rapinasa fiber which function prebiotics. Anthocyanins also have the ability to be antimutagenic and anti-carcinogenic against mutagens and carcinogens found in food and

\section{PENDAHULUAN}

Pangan lokal di Indonesia mempunyai peranan penting dalam mewujudkan ketahanan pangan nasional. Tanaman pangan seperti ubi jalar, jagung, ubi kayu dan sagu yang telah diolah menjadi tepung akan memiliki potensi yang besar sebagai bahan baku industri untuk menggantikan tepung terigu yang selama ini masih impor. Kebutuhan tepung terigu semakin tinggi dari tahun ke tahun akan tetapi, Indonesia bukan negara yang menghasilkan gandum yang merupakan bahan baku pembuatan tepung terigu.

Di Indonesia melakukan impor gandum untuk industri makanan pada tahun 2016, sekitar 8,1 juta ton, tetapi pada tahun 2017 terjadi peningkatan sebesar $4,8 \%$, padahal pada akhir tahun 2017 impor gandum mencapai 8,5 juta ton (Anggrawati et al., 2017). Dari data yang diperoleh bahan baku pengganti bahan baku untuk tepung terigu harus didapatkan agar Indonesia tidak terus menerus bergatung pada negara lain. Salah satu tanaman pangan yang processed ingredients, and can prevent disturbances in liver function, antihypertensives and reduce blood sugar levels. Processing sweet potatoes into flour is one way to store and preserve sweet potatoes. The use of sweet potatoes as a food source can also be used as industrial raw materials. Processing of sweet potatoes is also increasingly varied as the production of purple sweet potatoes increases. Processing into flour is a form of processed product that can increase national independence by reducing the use of wheat flour. Sweet potato can be processed into various modern preparations. Some processed foods that come from sweet potatoes are plain bread, steamed sponge, sweet potato noodles, sweet potato sticks, sweet potato jam, ice cream and sweet potato sauce.

dapat digunakan sebagai pengganti bahan baku tepung adalah ubi jalar.

Ubi jalar (Ipomoea batatas L) merupakan jenis umbi-umbian yang memiliki banyak kelebihan dibanding umbi-umbi lainnya dan merupakan sumber karbohidrat keempat terbesar di Indonesia, setelah beras, jagung, dan ubi kayu (Noer et al., 2017). Kandungan karbohidrat ubi jalar yang tinggi membuat ubi jalar dapat dijadikan sumber kalori. Kandungan karbohidrat ubi jalar tergolong indek glikemik rendah, yaitu tipe karbohidrat yang jika dikonsumsi tidak akan menaikkan kadar gula darah secara drastis (Murtniningsih dan Suryanti, 2011). Selain dapat diolah menjadi berbagai macam olahan makanan, ubi jalar juga merupakan salah satu sumber devisa negara dan Indonesia merupakan salah satu eksportir utama ubi jalar di pasar internasional. Tanaman ubi jalar bisa dibudidayakan baik di daerah dataran rendah maupun dataran tinggi (Kusumayanti dkk, 2016).

Ubi jalar memiliki potensi yang sangat besar sebagai bahan baku industri pangan. 
Sumber daya bahan tersedia juga melimpah, dikarenakan budidaya yang dilakukan cukup mudah dan mempunyai masa panen yang singkat. Ubi jalar juga mempunyai fleksibilitas yang tinggi dalam pengolahannya. Kandungan zat gizi ubi jalar tergolong cukup lengkap karena terdapat beberapa zat yang sangat penting bagi tubuh yaitu antosianin dan karatenoid sebagai anti oksidan serta serat rapinasa yang berfungsi prebiotik (Rosidah, 2014).

Ubi jalar merupakan salah satu komoditas pangan lokal yang mudah untuk dibudidayakan, khususnya di Papua Barat ada beberapa varietas lokal ubi jalar yang dihasilkan. Varietas lokal tersebut diantaranya adalah Manokwari, Nabire, Minyambouw, Aerani, Siepwauw, Ciceh, Numfor Putih, Warmare, dan Simpengguei, akan tetapi selama ini ubi jalar hanya dikonsumsi oleh masyarakat dalam bentuk utuh seperti direbus, digoreng, dibakar dan dikukus. Sedangkan pemanfaatan ubi jalar sebagai sumber pangan dapat juga dijadikan sebagai bahan baku industri. Ubi jalar dapat diolah menjadi aneka olahan moderen.

\section{PEMBAHASAN}

\section{Nilai Gizi Ubi Jalar}

Aneka umbi merupakan komoditas pertanian yang mempunyai kadar air antara 6070 persen. Dengan demikian hasil pertanian umbi-umbian mempunyao umur simpan jauh lebih pendek dibandingkan dengan komoditas serealia dan kacang-kacangan. Ubi jalar umumnya mengandung air 59-69\%, lemak 0,26-1,42\% (bk), abu 0,68-1,69\% (BK), protein $3,71-6,74 \%$ (BK) dan karbohidrat 91,42-
93,45\% (bk). Komposisi tersebut membuktikan bahwa ubi jalar tergolong sumber energi yang sangat potensial untuk dikembangkan dalam keanekaragaman konsumsi pangan. Pada $100 \mathrm{~g}$ ubi jalar mengandung berbagai vitamin, yaitu vitamin B1 (0,08 mg), vitamin B2 (0,05 mg), vitamin A (7100 IU), vitamin C (20 mg), serta vitamin B3 (0,9 mg) (Widowati, 2010).

Ubi jalar yang memiliki warna ungu pekat mengandung antosianin sebesar 61,85 mg/100 g atau sekitar 17 kali lebih besar dibandingkan dengan kandungan antosianin ubi jalar yang berwarna ungu muda yaitu 3,51 $\mathrm{mg} / 100 \mathrm{~g}$. Kandungan antosianin pada ubi ungu dapat berkurang ketika mengalami proses pengolahan, akan tetapi produk olahan yang dihasilkan masih tetap memiliki kandungan antosianin sebagai sumber antioksidan (Husna et al., 2013). Ubi jalar yang mempunyai warna pekat juga menandakan bahwa memiliki kadar betakarotinnya yang tinggi. Ubi jalar putih hanya mengandung betakarotin sebesar 260 mg/100 gram umbi, sedangkan ubi jalar ungu dan kuning mengandung betakarotin sebesar $2900 \mathrm{mg} / 100$ gram umbi (Ekoningtyas, 2016).

Ubi jalar ungu mempunyai manfaat bagi kesehatan karena terdapat kandungan antosianin yang cukup tinggi mulai dari 33.90 $\mathrm{mg} / 100 \mathrm{~g}$ sampai $560 \mathrm{mg} / 100 \mathrm{~g}$ yang bersifat antioksidan. Antosianin memiliki kecenderungan terpolimerisasi pada kondisi oksidatif seperti adanya paparan oksigen, cahaya, dan panas yang meyebabkan perubahan warna menjadi coklat, atau biasa disebut browning. Untuk mecegah terjadinya pencoklatan dan degradasi antosianin selama proses yang cukup panjang, maka ubi ungu 
perlu diberi perlakuan pendahuluan blansir uap dengan tujuan menginaktivasi enzim pendegradasi antosianin yang ada pada ubi ungu (Ticoalu, 2016).

Antosianin berperan dalam mencegah terjadinya penuaan dini, kanker dan penyakitpenyakit degeneratif, seperti atherosclerosis karena memiliki kemampuan sebagai antioksidan lebih tinggi dibandingkan dengan biji kedelai hitam, beras hitam dan terong ungu. Keunggulan lain antosianin adalah kemampuan sebagai antimutagenik dan antikarsinogenik terhadap mutagen dan karsinogen yang terdapat pada bahan pangan dan olahannya, sehingga dapat mencegah gangguan pada fungsi hati, antihipertensi dan menurunkan kadar gula darah (Widowati, 2010).

Senyawa antosianin memiliki manfaat sebagai antioksidan dan penangkap radikal bebas yang berperan untuk mencegah terjadi penuaan, kanker, dan penyakit degeneratif. Antosianin juga mempunyai kemampuan sebagai antimutagenik dan antikarsinogenik, mencegah gangguan fungsi hati, antihipertensi, dan menurunkan kadar gula darah (Jusuf et al., 2008)

\section{Pengolahan Tepung Ubi Jalar}

Menurut Juanda dan Cahyono (2000), saat ini pengolahan ubi jalar dalam bentuk bahan pangan lain untuk meningkatkan olahan ubi jalar masih dilakukan secara sederhana di Indonesia. Pengolahan ubi jalar menjadi tepung adalah salah satu cara untuk mengawetkan dan menyimpan ubi jalar. Tepung ubi jalar merupakan hancuran dari ubi jalar yang dihilangkan sebagian kadar airnya sekitar 7\% (Sarwono, 2007). Hilangnya atau kurangnya kandungan air pada tepung ubi jalar yang dihasilkan karena pada proses pengolahan ubi jalar menjadi tepung telah mengalami proses pengolahan panas yaitu pengeringan dengan menggunakan mesin pengering kabinet sehingga menyebabkan hilangnya air bebas dalam tepung (Noer dkk, 2017).

Tepung ubi jalar memiliki beberapa keunggulan antara lain: 1) lebih fleksibel dalam pengembangan produk pangan dan nilai gizi, 2) mempunyai daya simpan lebih panjang sehingga sebagai penyedia bahan baku industri dianggap penting karena menyebabkan harga lebih stabil, 3) menciptakan industri pada masyarakat tingkat desa dan memberi nilai tambah pendapatan serta meningkatkan mutu produk (Damardjati dkk, 1993). Beberapa hasil penelitian menyebutkan bahwa tepung ubi jalar dapat digunakan sebagai bahan campuran pada pembuatan berbagai produk makanan diantaranya mie, bihun, kue-kue kering, kue basah, dan roti tawar (Utomo dan Antarlina, 2002).

Proses pengolahan tepung ubi jalar yang pertama adalah penyortiran ubi jalar terlebih dahulu. Setelah mendapatkan ubi jalar yang diinginkan kemudian dilakukan pengupasan kulit ubi jalar, dicuci sampai bersih menggunakan air yang mengalir, dimana pencucian ini bertujuan untuk membersihkan ubi jalar dari adanya sisa kotoran dan tanah. Ubi jalar yang sudah disortir, kemudian dikupas lalu dicuci, diiris tipis dengan ketebalan kurang lebih $1 \mathrm{~mm}$ kemudian direndam dalam air untuk menghilangkan getahnya. Pengirisan ini mempunyai tujuan untuk mempercepat pengeringan dan memudahkan dalam proses 
penepungan ubi jalar. Ubi jalar yang telah diiris dapat ditiriskan dan dikeringkan menggunakan dryer dengan suhu 60 derajat celcius selama 5 jam. Langkah selanjutnya yaitu dilakukan penepungan menjadi halus, tepung ubi jalar yang dihasikan diayak menggunakan ayakan sampai diperoleh tepung ubi jalar dengan ukuran 40-60 mesh (Kusumayanti dkk, 2016).

Tepung ubi ungu mempunyai kandungan karbohidrat sebesar 77.89\%, kandungan protein sebesar 8.99\%; kandungan lemak sebesar 0.45\%; kandungan kadar air sebesar 11. 17\%; dan kandungan kadar abu sebesar $1.49 \%$. Kandungan tersebut didapat apabila proses pengeringan tepung dengan cara dijemur. Sedangkan tepung ubi ungu yang dikeringkan dengan cara dioven mempunyai kandungan karbohidrat sebesar $79.3805 \%$, kandungan protein sebesar 9.03\%; kandungan lemak sebesar 0.39\%; kandungan kadar air sebesar 9.59\%; dan kandungan kadar abu sebesar $1.60 \%$ (Rijal, 2019)

Ubi jalar yang dibiarkan lama biasannya akan berubah warna menjadi gelap karena adanya aktivitas enzim polifenol oksidase. Untuk mencegah terjadinya perubahan warna, irisan ubi jalar dapat direndam dalam larutan natrium bisulfit $0,2 \%$ berat selama $10-15$ menit dengan perbandingan air rendaman dan umbi 3 liter : $1 \mathrm{~kg}$ (Ginting et al., 2008). Keunikan dari tepung ubi jalar adalah warna tepung yang bermacam-macam sesuai dengan warna daging umbi bahan bakunya. Proses yang sesuai akan dapat menghasilkan tepung yang memiliki warna sesuai dengan umbi bahan. Sedangkan, proses yang kurang sesuai dapat mengakibatkan penurunan mutu tepung, yang mana hasil tepung akan berwarna kusam, gelap, atau kecokelatan. Untuk menghindari hal tersebut disarankan untuk merendam irisan ubi jalar selama kurang lebih satu jam (Widowati, 2009).

Tepung ubi jalar ungu memiliki tekstur sama seperti tepung pada umumnya dan mempunyai ungu keputihan, tetapi setelah terkena air akan berwarna ungu tua. Proses pengeringan pada pembuatan tepung ubi jalar penting untuk diperhatikan supaya mendapatkan hasil tepung yang berkualitas. Pengeringan adalah salah satu cara untuk mengurangi sebagian air dari suatu bahan dengan cara diuapkan (Nurdjanah dan Neti, 2019).

\section{Aneka Olahan Ubi Jalar}

Pengolahan ubi jalar semakin lama sangat bervariasi seiring dengan meningkatnya produksi. Pengolahan ubi jalar menjadi tepung adalah salah satu cara yang dapat dilakukan untuk mengurangi penggunaan tepung terigu (Djami, 2007). Adapun beberapa olahan yang berasal dari tepung ubi jalar sebagai berikut.

\section{Roti Tawar}

Pengolahan tepung ubi jalar menjadi roti tawar dengan menggunakan bahan-bahan kering, yakni tepung terigu, tepung ubi jalar, instant yeast, gula pasir, susu skim bubuk, pengembang, dan garam dicampur dengan mixer hingga merata serta ditambah air sedikt demi sedikit dan diaduk hingga terbentuk adonan. Tambahkan shortening sambil tetap diaduk sampai terbentuk adonan yang kalis. Selanjutnya adonan dibentuk bulat dan didiamkan selama 10 menit agar mengembang. Langkah selanjutnya adalah memotong adonan dan menimbang serta dibentuk bulat-bulat lalu 
diamkan kembali selama 15 menit. Kemudian, setiap bulatan adonan digiling menggunakan gilingan kayu atau rolling pin lalu dibalik dan digulung,. Setelah itu dapat dimasukkan ke dalam loyang yang telah dioles margarin, kemudian dimasukkan ke dalam proofer dan didiamkan kembali selama satu jam. Selanjutnya, adonan beserta cetakkannya dimasukkan ke dalam oven dengan suhu 190 derajat celcius selama 25 menit (sampai matang) dan didinginkan hingga diperoleh roti tawar (Hardoko et al., 2010).

\section{Bolu Kukus}

Pengolahan tepung ubi jalar menjadi bolu kukus diawali dengan mempersiapkan alat dan bahan yang dibutuhkan, beri 1 atau 2 lembar kertas cup di setiap cetakan, isi air kedalam pengukus secukupnya. Selanjutnya menimbang semua bahan yaitu gula pasir $100 \mathrm{~g}$, minuman bersoda $200 \mathrm{ml}$, emulsifier $10 \mathrm{~g}$, vanilla bubuk $2 \mathrm{~g}$ dan masing-masing tepung ubi jalar di timbang sebanyak $100 \mathrm{~g}, 125 \mathrm{~g}$, dan $150 \mathrm{~g}$. Apabila sudah siap, campurkan masing-masing adonan tepung ubi jalar kedalam wadah, aduk adonan hingga benar-benar tercampur rata menggunakan mixer sampai adonan menjadi kental dan mengembang kemudian tuang adonan kedalam cetakan. masukkan semua cetakan ke dalam pengukus yang sudah disiapkan sebelumnya. Berikan alas pada bagian penutup dandang dengan kain, supaya air dari uap panasnya tidak menetes pada adonan. Kukus menggunakan api besar selama 15 menit. Uap air yang panas akan membuat bolu kukus mekar dengan sempurna (Noer et al., 2017).

\section{Mie Ubi Jalar}

Proses pengolahan mie ubi jalar diawali dengan pencampuran pasta dengan telur, garam dan bumbu hingga terbentuk adonan dan kemudian digiling menggunakan gilingan mie. Selanjutnya adonan yang sudah digiling tersebut direbus atau dikukus sebentar untuk mendapatkan mie basah sedangkan adonan juga dapat dikeringkan dengan oven untuk mendapatkan mie kering. Warna mie ubijalar cukup menarik, terutama yang berasa dari ubijalar jingga dan ungu (Ginting et al., 2014).

\section{Selai}

Pembuatan selai dari ubi jalar mempunyai proses yang sama seperti pembuatan selai buah-buahan. Langkah pertama, ubi jalar rebus dihaluskan menggunakan blender dengan tambahan air $30 \%$, lalu panaskan dan tambahankan gula sebanyak $44 \%$, setelah terbentuk selai dapat langsung dinikmati atau disimpan kedalam wadah yang tertutup. Hasil analisis selai ubi jalar menunjukkan kekentalan berkisar antara 42.900-49.000 cps, pH 3,3-3,6, kadar gula sekitar 62 persen, dan vitamin A sebesar 1.600 SI (Widowati, 2010).

\section{Stik Ubi Jalar}

Produk stik ubijalar dapat dikembangkan seperti kentang atau French fries yang harganya menjadi sedikit mahal. Ubijalar yang dipilih sebagai bahan baku harus baik agar produk yang dihasilkan renyah bila digoreng dan memiliki rasa yang gurih. Proses pembuatannya meliputi pencucian umbi, pengupasan, perendaman dalam air, perajangan memanjang (bentuk stik), blanching dengan cara perebusan dalam air mendidih selama 7,5-10 menit, 
penirisan, pemberian bumbu (garam, bawang putih, soda kue, sedikit air), penggorengan, penirisan minyak (sentrifugasi), pengemasan dalam kantong plastik (Ginting et al., 2011).

\section{Es Krim}

Langkah pertama dalam pembuatan es krim ubi jalar yaitu dengan menyiapkan air rebusan ubi jalar sebanyak $600 \mathrm{ml}$ dari $1 \mathrm{~kg}$ irisan ubi jalar yang direbus dengan 2 liter air hingga mendidih. Setelah mendidih, air rebusan diambil sebanyak $600 \mathrm{ml}$, sedangkan irisan ubi jalar ungu diambil sebanyak 150 gr sebagai pasta. Kemudian, air rebusan dimasukkan dalam freezer sampai hampir beku. Setelah terbentuk langit-langit es, air rebusan diaduk dengan mixerkecepatan tinggi dicampur tepung es krim bermerk Whipped Cream (150 gr) dan susu kental manis (385 gr). Setelah adonan kental dengan pengadukan selama 15 menit, pasta ubi jalar ungu yang sudah dilumatkan dimasukkan dalam adonan es krim, kemudian segera dikemas dan dimasukkan kedalam freezer (Harwati et al., 2011).

\section{Saos Ubi Jalar}

Ubi jalar berukuran kecil yang selama ini tidak laku dijual, ternyata dapat digunakan sebagai bahan bakusaos yang kualitasnya sama dengan dengan 100\%ubi jalar berukuran besar. Langkah pembuatannya yang pertama adalah mencuci ubi jalar dan mengukus selama 30 menit, setelah itu dilakukan pengupasan kulit ubi. Langkah selanjutnya adalah pelumatan ubi jalar dengan menggunakan blender dengan menambahkan air, bawang putih, merica bubuk, cabe bubuk, garam dan gula pasir. Selanjutnya adonan saos di masak dan diaduk selama 15 menit. Setelah itu tambahkan jahe, cuka dan pewarna makanan dan masak serta aduk kembali adonan selama 5 menit. Saos ubi jalar sudah bisa digunakan (Ginting et al., 2006).

\section{KESIMPULAN DAN SARAN}

Ubi jalar merupakan salah satu komoditas pangan lokal yang mudah untuk dibudidayakan, khususnya di Papua Barat ada beberapa varietas lokal ubi jalar yang dihasilkan. Selama ini ubi jalar hanya dikonsumsi oleh masyarakat dalam bentuk utuh seperti direbus, digoreng, dibakar dan dikukus. Aneka umbi merupakan komoditas pertanian yang mempunyai kadar air tinggi, yaitu antara 60-70 persen sehingga umur simpan jauh lebih pendek dibandingkan dengan serealia dan kacang-kacangan.

Pengolahan ubi jalar menjadi tepung merupakan salah satu cara untuk menyimpan dan mengawetkan ubi jalar. Tepung ubi jalar merupakan hancuran dari ubi jalar yang dihilangkan sebagian kadar airnya. Pemanfaatan ubi jalar sebagai sumber pangan dapat juga dijadikan sebagai bahan baku industri. Ubi jalar dapat diolah menjadi aneka olahan moderen. Beberapa olahan makanan yang berasal dari ubi jalar adalah roti tawar, bolu kukus, mie ubi jalar, stik ubi jalar, dan selai ubi jalar.

\section{DAFTAR PUSTAKA}

Anggrawati, N. Ekawati \& Wiadnyani. (2019). Pengaruh Substitusi Tepung Ubi Jalar Ungu Termodifikasi (Ipomoea Batatas Var Ayamurasaki) Terhadap Karakteristik Waffle. Jurnal Ilmu dan Teknologi Pangan Vol. 8, No. 2.

Damardjati, D.S., S. Widowati \& Suismono. (1993). Pembinaan Sistem Agroindustri Tepung Kasava Pola Usaha Tani Plasma di Kabupaten Ponorogo. Laporan 
Penelitian Kerjasama Balittan

Sukamandi dengan PT. Petro Aneka Usaha. Sukamandi.

Djami, S.A. (2007). Prospek Pemasaran Tepung Ubi Jalar ditinjau dari Potensi Permintaan Industri Kecil di Wilayah Bogor. Skripsi. Institut Pertanian Bogor.

Ekoningtyas E. A. (2016). Potensi Kandungan Kimiawi Dari Ubi Jalar Ungu (Ipomoea Batatas L) Sebagai Bahan Identifikasi Keberadaan Plak Pada Permukaan Gigi. Jurnal Kesehatan Gigi Vol.03 No.1.

Ginting, E. Joko,S. Rahmi,Y. \& M. Jusuf. (2011). Ubijalar Sebagai Bahan Diversifikasi Pangan Lokal. Iptek Tanaman Pangan. Vol. 6 No. 1.

Ginting, E. Rahmi,Y., \& M. Jusuf. (2014). Ubijalar Sebagai Bahan Diversifikasi Pangan Lokal. Balai Penelitian Tanaman Aneka Kacang dan Umbi. Malang.

Ginting, E., Sri, S. A., Joko, \& S. Ratnaningsih. (2006). Teknologi Pasca Panen Ubi Jalar Mendukungdiversifikasi Pangan Dan Pengembangan Agroindustri. Buletin Palawija No. 11.

Ginting, E., S. S. Antarlina, I. Sudaryono, A. Winarto, \& Sugiono. (2008). Resep produk olahan umbi-umbian dan kacangkacangan, Balitkabi, Malang.

Hardoko, L. H., \& Siregar, T. M. (2010). Pemanfaatan Ubi jalar (Ipomea batatas L. Poir) sebagai Pengganti Sebagian Tepung Terigu dan Sumber Antioksidan pada Roti Tawar. Jurnal Teknologi dan Industri Pangan. Vol. 21 No.1.

Harwanti S., T. Zubaidi, \& S.S. Antarlina. (2011). Ubi jalar ungu sebagai bahan baku pembuatan es krim. Prosiding Seminar Nasional 2nd National Conference on Green Technology-Eco Technology for Sustainable Living. Hal G-128 sampai G-133. Malang, 12 November 2011.

Husna, N., Melly, N., \& Syarifah, R. (2013). Kandungan Antosianin Dan Aktivitas Antioksidan Ubi Jalar Ungu Segar Dan Produk Olahannya. Jurnal Agritech, Vol. 33 No. 3.
Juanda, D. \& Cahyonod, B. (2000). Ubi Jalar Budidaya dan analisis Usaha Tani. Kanisius. Yogyakarta.

Jusuf, M., Rahayuningsih, St. A. \& Ginting, E. (2008). Ubi jalar ungu. Warta Penelitian dan Pengembangan Pertanian 30: 13-14.

Kusumayanti, H., Ahmad, L., Setiawati \& Ginting. (2016). Pengolahan Ubi Jalar (Ipomoea batatas L) Dengan Sistem Kering Untuk Meningkatkan Komoditas Pangan Lokal. Jurnal Metana. Vol. 12 No. 2.

Mutiningsih \& Suryati. (2011). Membuat Tepung Umbi dan Varietas Olahannya. Agromedia. Jakarta.

Noer, S.W., Mohammad, W., \& Kardiman. (2017). Pemanfaatan Tepung Ubi Jalar (Ipomea Btatas L) Berbagai Varietas Sebagai Bahan Baku Pembuatan Kue Bolu Kukus. Jurnal Pendidikan Teknologi Pertanian. Vol. 3.

Nurdjanah, S., \& Neti, Y. (2019). Ubi Jalar Teknologi Produksi dan Karakteristik Tepung Ubi Jalar Ungu Termodifikasi. Penerbit Aura. Lampung.

Rijal, M., Nur, A., \& Idrus, S. (2019). Analisis Kandungan Zat Gizi Pada Tepung Ubi Ungu (Ipomoea Batatas Varietas Ayumurasaki) Dengan Pengeringan Sinar Matahari Dan Oven. Jurnal Biotek Vol 7 No 1.

Rosidah. (2014). Potensi Ubi Jalar Sebagai Bahan Baku Industri Pangan. Teknobuga Volume 1 No.1.

Sarwono, B. (2007). Ubi Jalar. Penebar Swadaya. Jakarta.

Ticoalu, G., Yunianta, \& Jaya, M. (2016). Pemanfaatan Ubi Ungu (Ipomoea Batatas) Sebagai Minuman Berantosianin Dengan Proses Hidrolisis Enzimatis. Jurnal Pangan dan Agroindustri Vol. 4 No 1.

Utomo, J.S. \& S.S. Antarlina. (2002). Tepung Instant Ubi Jalar untuk Pembuatan Roti Tawar. Majalah Pangan No: 38/XI/Jan/2002 Hal: 28-34.

Widowati, S. (2010). Diversifikasi Konsumsi Pangan Berbasis Ubi Jalar. Balai Penelitian dan Pengembangan Pascapanen Pertanian. Bogor. 
Widowati, S. (2009). Tepung Aneka Umbi:

Sebuah Solusi Ketahanan Pangan.

Tabloid Sinar Tani, 6 Mei 2009.

Zuraida, N. \& Supriati, Y. (2001). Usaha Tani Ubi Jalar sebagai Bahan Pangan Alternatif dan Diversifikasi Sumber Karbohidrat. Buletin Agro Bio. 4(1): 1323. 